\title{
PERUBAHAN POLITIK LUAR NEGERI RUSIA TERHADAP SURIAH DALAM KONFLIK INTERNAL SURIAH (2011-2017)
}

\author{
Fatmawati \\ IImu Politik, Pascasarjana FISIP Universitas Riau \\ fatmawati633@gmail.com
}

\begin{abstract}
Abstrak
Sejak awal konflik Suriah pada tahun 2011, Rusia sebagai sekutu penting bagi Suriah telah mendukung pemerintah Assad untuk mempertahankan rezim Assad. Rusia telah berperan sebagai pendukung langsung terhadap rezim Assad melalui dukungan non-militer, menyalurkan bantuan ekonomi, dan dukungan militer dalam bentuk kerjasama militer. Namun, setelah jatuhnya kota Aleppo, yang mewakili koalisi besar pasukan pendukung rezim sejak intervensi militer Rusia pada September 2015, Rusia telah mengubah politik luar negerinya dalam konflik Suriah. Rusia dengan cepat mengadakan pertemuan tripartit di Moskow yang melibatkan Turki dan Iran untuk menyepakati prinsip damai yang dikenal sebagai Deklarasi Moskow. Dari aspek militer, Rusia telah mengurangi sejumlah besar peralatan dan pasukan militer di Suriah. Penelitian ini akan membahas bentuk perubahan politik luar negeri Rusia terhadap Suriah dalam konflik internal Suriah antara tahun 2011 dan 2017 melalui konsep dukungan non-militer, kerjasama militer, mediasi, negosiasi, dan peace making. Penelitian ini menggunakan pendekatan penelitian kualitatif dengan jenis penelitian deskriptif dan mengumpulkan data sekunder dari berbagai sumber yang telah dipublikasikan. Temuan penelitian ini menunjukkan bahwa adanya pola dari bentuk perubahan politik luar negeri Rusia dari pendukung langsung rezim Assad ke mediator dalam konflik internal Suriah antara tahun 2011 dan 2017.
\end{abstract}

Kata kunci:

Konflik Suriah, politik luar negeri, pendukung langsung, dan mediator.

\begin{abstract}
Since the beginning of Syrian conflict in 2011, Russia as an important ally for Syria had supported the Assad's government in order to defend Assad's regime. Russia acted as a direct supporter to Assad's regime through non-military support, deploying economic assistance, and military support in the form of military cooperation. However, after the fall of the city of Aleppo, which represented a major coalition of forces supporting the regime since Russian military intervention in September 2015, Russia has changed its foreign policy in Syrian conflict. Russia hastened to hold a tripartite meeting in Moscow that involved Turkey and Iran to agree on the principles of peace in Syria which was known as Moskow Declaration. From military aspect, Russia reduced a large number of equipments and military forces in Syria. This research will discuss an overview form of Russia's foreign policy changes to Syria in the Syrian internal conflict between 2011 and 2017 through the concept of non-military support, military cooperation, mediation, negotiation, and peace making. This research applied qualitative research approach with descriptive research type and collected secondary data from various sources that have been published. The finding of this research showed that there was a pattern of form of Russia's foreign policy changes from direct supporter of Assad's regime to mediator in the Syrian internal conflict between 2011 and 2017.
\end{abstract}

Keywords:

Syrian Conflict, foreign policy, direct supporter, and mediator 


\section{PENDAHULUAN}

Sebuah fenomena revolusi yang menganggu stabilitas politik di negara-negara kawasan Timur Tengah sejak awal tahun 2011 dikenal dengan Arab Spring (Tamburaka 2011: 7). Peristiwa yang mengakibatkan runtuhnya banyak rezim berkuasa ini berawal dari Tunisia, kemudian menyebar ke Yordania, Mesir, Aljazair, Yaman, Bahrain, Libya dan Suriah. Konflik Suriah yang dimulai dengan aksi demontrasi bertujuan untuk menurunkan rezim Bashar al-Assad yang dianggap tiran, berujung pada konflik bersenjata antara kelompok pemberontak (Free Syrian Army dan Syrian National Council/Coalition) dan pemerintah Suriah. Memasuki tahun keenam, konflik Suriah semakin rumit karena semakin banyaknya negara lain yang terlibat dan didasarkan atas kepentingan nasional masing-masing (Shaheen, Kareem, Torpey, Paul, Gutiérrez, Pablo, Levett 2015). Dua negara yang menentang rezim Bashar al-Assad, yaitu Amerika Serikat dan Turki. Sementara di lain pihak, tiga negara yang berpihak pada rezim Bashar al-Assad, yaitu Rusia, Cina dan Iran.

Rusia merupakan negara yang paling aktif dalam mendukung rezim Bashar al-Assad diantara ketiga negara tersebut (Hearst 2012). Keterlibatan Rusia di Suriah tidak terlepas dari kepentingan nasionalnya di Suriah. Bagi Rusia, Suriah memiliki nilai strategis baik secara militer, politik maupun ekonomi. Dalam aspek militer, Rusia ingin tetap mempertahankan pangkalan militer Rusia yang terletak di pelabuhan Tartus sebagai satu-satunya pangkalan Angkatan Laut Rusia di kawasan Timur Tengah dan Mediterania (Kreutz 2010: 8-10). Sementara dari segi politik, Suriah memiliki posisi yang strategis bagi Rusia dalam memperkuat pengaruhnya di kawasan Timur Tengah. Dalam aspek ekonomi, Suriah merupakan salah satu pasar terbesar Rusia di kawasan Timur Tengah, khususnya dalam penjualan senjata.

Suriah merupakan sekutu terdekat Rusia di kawasan Timur Tengah. Hubungan antara Rusia dan Suriah mulai terjalin pada tahun 1946, yaitu ketika Hafez al-Assad memimpin Suriah (Sharnoff 2009). Perkembangan hubungan kedua negara semakin dekat setelah pecahnya revolusi di Suriah. Rusia terlibat dalam konflik Suriah sejak tahun 2011 dan menjadi salah satu aktor pemain regional utama dalam konflik tersebut. Intervensi Rusia dalam konflik Suriah dimulai dengan mendukung rezim Bashar al-Assad sebagai pemerintah sah rakyat Suriah. Secara luas diakui bahwa, tujuan langsung intervensi militer Rusia di Suriah adalah untuk mencegah penggulingan Presiden Bashar al-Assad oleh kelompok pemberontak. Rusia tidak ingin rezim Bashar al-Assad yang berkuasa di Damaskus jatuh, seperti pemimpin di Libya (Austin 2017).

Rusia telah memberikan dukungan yang luas terhadap rezim Bashar alAssad, baik secara militer maupun non-militer. Dari tahun 2011-2015, Rusia telah empat kali menjatuhkan veto terhadap rancangan resolusi Dewan Keamanan (DK) PBB terkait Suriah. Menurut Rusia, resolusi DK PBB yang ditujukan atas konflik Suriah membuka peluang bagi pihak asing untuk melakukan intervensi dalam konflik tersebut yang akan melanggar hak-hak kedaulatan Suriah (Menon 2012). Selanjutnya, Rusia menyalurkan bantuan keuangan melalui pinjaman uang dan layanan perbankan Rusia terhadap pemerintah Suriah (Wilson 2014). Tidak hanya dukungan non-militer, Rusia juga memberikan dukungan militer berupa kerjasama militer terhadap rezim Bashar al-Assad (Baczynska 2015). Secara konsisten, Rusia juga telah menolak mendukung sanksi sepihak yang diberikan oleh Amerika Serikat, Uni Eropa dan Liga Arab untuk menerapkan embargo senjata dan sanksi ekonomi 
terhadap Suriah untuk menghentikan penindasan terhadap para penentang rezim Bashar al-Assad (Leidhoidt, Ulrich dan Saloh 2012).

Kini, setelah pasukan pemerintah Suriah yang didukung militer Rusia berhasil merebut Aleppo pada akhir tahun 2016, Presiden Rusia, Vladimir Putin menyatakan ingin bertindak sebagai pembawa perdamaian di Suriah (Russia Beyond 2017). Semakin meningkatnya ancaman yang ditimbulkan oleh terorisme yang mengancam keamanan domestik Rusia, juga mendorong Rusia untuk mengubah politik luar negerinya dalam konflik Suriah. Hal ini berkaitan dengan pernyataan resmi dari misi yang disampaikan oleh Vladimir Putin, yaitu perang melawan terorisme internasional (Rosenberg 2017).

Rusia telah beralih sikap menjadi lebih moderat bersama Turki dan Iran dalam penyelesaian konflik Suriah. Pada akhir tahun 2016, Rusia menyelenggarakan konferensi tripartit bersama Turki dan Iran di Moskow untuk mengakhiri konflik Suriah (Filipov, David 2016). Selanjutnya, pada awal tahun 2017, Rusia juga menginisiasi dan memimpin perundingan perdamaian di Astana, Kazakhstan, yang pertama kalinya menghadirkan kelompok pemberontak dan perwakilan pemerintah Suriah untuk duduk bersama dalam arena internasional, guna mencari solusi damai pada konflik Suriah (Sly 2017). Bukan hanya mengadakan beberapa pertemuan damai, Rusia juga mengurangi sejumlah besar kehadiran peralatan dan pasukan militernya di Suriah guna mendukung upaya perdamaian dalam konflik Suriah (Aliyeva 2017). Berdasarkan latar belakang yang telah diuraikan, adapun rumusan masalah dalam penelitian ini adalah "Bagaimana bentuk perubahan politik luar negeri Rusia terhadap Suriah dalam konflik internal Suriah (2011-2017)?"

\section{KERANGKA TEORITIS}

Menurut Cobb, dukungan sosial adalah suatu bentuk kenyamanan, perhatian, penghargaan atau bantuan yang diterima individu dari orang-orang yang berarti, baik secara perorangan maupun kelompok (Sarafindo 1997: 32). Dalam konteks hubungan antar negara, dukungan adalah suatu bentuk bantuan yang berasal dari suatu negara yang memiliki hubungan sosial yang akrab dengan negara lain. Dukungan yang secara langsung diberikan oleh suatu negara terhadap negara lain dan didasarkan atas kepentingan nasionalnya disebut dengan dukungan langsung. Sementara, aktor negara yang memberikan dukungan langsung tersebut dapat disebut sebagai pendukung langsung (direct supporter). Salah satu bentuk dari dukungan adalah kerjasama. Hubungan kerjasama muncul karena adanya kebutuhan masing-masing negara yang berbeda, sedangkan kemampuan dan potensi yang dimiliki pun juga tidak sama. Suatu kerjasama yang dimungkinkan apabila terdapat dua kekuatan yang satu dengan lainnya memiliki kesamaan dalam masalah keamanan disebut kerjasama militer. Kerjasama militer merupakan bentuk asosiasi mengikat yang dapat disesuaikan dengan kepentingan-kepeningan suatu negara dalam menghadapi persoalan tertentu, sehingga dimungkinkan apabila dalam kerjasama ini akan melemah, berarti negara bersangkutan dihadapkan dengan permasalahan baru. Menurut Joshua, kerjasama atau aliansi merupakan koalisi dari beberapa negara yang mengkoordinir tindakan mereka untuk memenuhi beberapa tujuan akhir (Goldstein 1994: 46).

Mediasi diartikan sebagai prosedur yang didasarkan pada proses negosiasi. Mediasi sebagai proses dimana para pihak, bersama untuk mendapatkan bantuan 
netral dan secara sistematis mengisolasi isu-isu yang disengketakan untuk mengembangkan pilihan, mempertimbangkan alternatif dan mencapai penyelesaian konsensual yang akan mengakomodasi kebutuhan pihak yang berkonflik (Folberg 1984: 7). Sementara, pihak ketiga yang netral dalam proses mediasi sebagai elemen pengatur komunikasi dalam suatu masalah disebut dengan mediator. Mediator dapat memasuki konflik, baik internal maupun internasional, untuk mempengaruhi konflik, mengubah peta konflik, mengatasi konflik dan memodifikasi konflik dengan cara tertentu. Mediator sadar atau tidak, membawa gagasan, pengetahuan, sumber daya dan kepentingan mereka sendiri atau kelompok atau organisasi yang mereka wakili. Mediator memiliki asumsi dan agenda mereka sendiri mengenai konflik tersebut.

Adapun unsur mediasi adalah negosiasi. Menurut Harold Saunders, proses negosiasi melibatkan empat fase yang berbeda, yaitu mengidentifikasi masalah, mengembangkan komitmen, menetapkan kerangka negosiasi dan melakukan negosiasi (Mark R. Amstutz 1999: 320-321). Adapun proses mediasi dan negosiasi yang dilakukan oleh mediator, bertujuan untuk menghasilkan kesepakatan damai dalam suatu konflik. Menurut Johan Galtung, salah satu cara membangun perdamaian atau salah satu model yang dapat digunakan sebagai proses resolusi konflik adalah upaya peace making melalui proses mediasi dan tahapan negosiasi (Galtung 1996: 21). Model ini sebagai proses yang bertujuan untuk mempertemukan atau merekonsiliasi sikap politik dan strategi dari pihak yang bertikai dan memliki perbedaan kepentingan didalamnya melalui upaya mediasi dan negosiasi terutama pada level elit atau pimpinan untuk menciptakan suatu perdamaian. Peace making juga diartikan sebagai sebagai sebuah upaya diplomatis yang dapat dilakukan dengan menghadirkan pihak ketiga sebagai penengah untuk menyelesaikan permasalahan antara pihak yang berkonflik, tanpa tindakan kekerasan yang berujung pada perjanjian damai.

Dukungan yang telah diberikan oleh Rusia terhadap suriah dalam konflik internal suriah adalah dukungan non-militer dan militer. Rusia sebagai sekutu terpenting Suriah telah mengarahkan politik luar negerinya untuk menjadi direct supporter terhadap pemerintah Suriah sejak konflik Suriah terjadi pada tahun 2011. Dukungan Rusia terhadap rezim Assad meliputi, dukungan non-militer berupa veto terhadap draft resolusi Dewan Keamanan (DK) PBB yang ditujukan kepada pemerintah Suriah dan dukungan ekonomi berupa pinjaman uang dan layanan perbankan Rusia terhadap pemerintah Suriah serta dukungan militer berupa kerjasama militer antara Rusia dan Suriah dalam konflik Suriah. Secara konsisten, Rusia sebagai salah satu dari lima anggota permanen DK PBB telah menggagalkan draft resolusi DK PBB terkait Suriah sebanyak empat kali dalam kurun waktu 20112015. Dalam setiap penggunaan hak vetonya, Rusia memiliki alasan dan perspektif tersendiri dalam melihat konflik Suriah. Moskow memandang bahwa penyelesaian terbaik konflik Suriah adalah melalui upaya perdamaian secara politik, bukan melimpahkan konflik pada organisasi internasional. Bukan hanya melalui jalur diplomatik, Rusia juga menyalurkan bantuan ekonomi kepada pemerintah Suriah berupa pinjaman uang dan beberapa bantuan ekonomi lainnya.

Bukan hanya terbatas pada dukungan non-militer, Rusia juga memberikan dukungan militer berupa kerjasama militer. Hubungan kerjasama militer antara Rusia dan Suriah sudah berlangsung sejak terjadinya Perang Dingin. Hubungan kerjasama militer antara kedua negara tersebut terus berlanjut hingga konflik Suriah bergejolak pada tahun 2011. Revolusi di Suriah menyebabkan peran militer Rusia lebih besar dari pada sebelumnya. Rusia tetap membuat perjanjian atau kontrak militer dengan 
Suriah selama konflik berlangsung, memberikan pasokan persenjataan dan peralatan militer terhadap pemerintah Bashar al-Assad, mengirimkan prajurit dan penasihat militer ke Suriah dan memperluas basis militer di pangkalan udara Latakia, Suriah (SBS News 2013).

Setelah pasukan pemerintah Suriah yang didukung oleh militer Rusia berhasil mendorong kelompok pemberontak keluar dari wilayah Aleppo pada akhir tahun 2016, Rusia telah mengubah politik luar negerinya dari direct supporter beralih sikap menjadi mediator yang netral atau penjamin dalam upaya untuk menghentikan konflik Suriah. Presiden Rusia, Vladimir Putin menyatakan bahwa hanya solusi politik yang dapat mengakhiri konflik di Suriah (BBC News 2016). Rusia menjadi peran utama dalam menengahi proses perdamaian di dalam konflik Suriah. Moskow menjadi pihak ketiga sebagai penjamin dalam menyelesaikan konflik di Suriah melalui upaya mediasi, negosiasi dan peace making. Vladimir Putin menjadikan Rusia sebagai kekuatan politik utama untuk bisa duduk di meja perundingan internasional bersama Turki dan Iran serta mendiskusikan cara untuk menyelesaikan konflik Suriah yang paling penting saat ini.

Rusia telah mengadakan pertemuan tripartit di Moskow pada 20 Desember 2016 bersama Turki dan Iran untuk menyepakati prinsip-prinsip solusi politik di Suriah. Pertemuan trilateral antara ketiga negara tersebut diformalkan dalam sebuah perjanjian, yaitu Deklarasi Moskow delapan poin sebagai peta jalan untuk mengakhiri konflik Suriah (Friedman 2017: 5). Selama tahun 2011-2017, Rusia, Turki dan Iran telah melakukan delapan perundingan perdamaian di Astana, Kazakhstan sebagai bentuk dari proses negosiasi untuk mencapai alternatif pilihan kebijakan dalam penyelesaian konflik Suriah. Proses mediasi dalam konflik Suriah melibatkan delegasi dari Rusia, Turki, Iran, pihak kelompok pemberontak, perwakilan pemerintah Suriah, negara-negara lainnya dan Perserikatan BangsaBangsa (PBB). Rusia bersama Turki dan Iran menyelenggarakan pertemuan perdamaian yang berkelanjutan guna mencapai beberapa kesepakatan dalam mencari solusi konflik Suriah, seperti pembentukan mekanisme gencatan senjata nasional antara pemerintah Suriah dan pihak kelompok oposisi serta membentuk zona de-eskalasi di beberapa bagian negara Suriah (Lee 2017). Dari aspek militer, Rusia telah mengurangi sejumlah besar peralatan militer dan kehadiran pasukan militer di Suriah untuk kembali ke markas masing-masing di Rusia atas keputusan dari Presiden Rusia, Vladimir Putin. Adanya upaya Rusia untuk melakukan proses negosiasi dengan Turki, Iran dan pihak pemerintah Suriah serta kelompok oposisi di Moskow sehingga menghasilkan Deklarasi Moskow dan menjadi mediator di Astana, Kazakhstan demi terciptanya perdamaian di Suriah, mengindikasikan bahwa Rusia telah melakukan implementasi salah satu model resolusi konflik, yaitu peace making.

Operasionalisasi Konsep

\begin{tabular}{|c|l|l|l|}
\hline No. & \multicolumn{1}{|c|}{ Konsep } & \multicolumn{1}{|c|}{ Variabel } & \multicolumn{1}{c|}{ Indikator } \\
\hline 1. & Dukungan & Rusia sebagai direct \\
non-militer & supporter terhadap & 1. Veto terhadap draft \\
dan & resolusi DK PBB \\
& kerjasama \\
militer & internal Suriah & 2. Bantuan Ekonomi \\
& & & $\begin{array}{l}\text { 3. Kontrak militer } \\
\text { 4. Pasokan persenjataan } \\
\text { dan peralatan militer }\end{array}$ \\
& & 5. Pengiriman pasukan \\
\hline
\end{tabular}




\begin{tabular}{|c|l|l|l|}
\hline & & $\begin{array}{l}\text { dan penasihat militer } \\
\text { 6. Perluasan basis militer }\end{array}$ \\
\hline 2. & $\begin{array}{l}\text { Mediasi, } \\
\text { negosiasi } \\
\text { dan peace } \\
\text { making }\end{array}$ & $\begin{array}{l}\text { Rusia sebagai mediator } \\
\text { terhadap Suriah dalam } \\
\text { konflik internal Suriah }\end{array}$ & $\begin{array}{l}\text { 1. Deklarasi Moskow } \\
\text { 2. Perundingan } \\
\text { perdamaian Astana, } \\
\text { Kazakhstan } \\
\text { 3engurangan } \\
\text { penyebaran peralatan } \\
\text { militer }\end{array}$ \\
& & $\begin{array}{l}\text { 4. Pengurangan kehadiran } \\
\text { pasukan militer }\end{array}$ \\
\hline
\end{tabular}

\section{Model Analisis}

\begin{tabular}{|c|}
\hline Dukungan non-militer \\
- Veto terhadap draft \\
\hline Kerjasanha militer \\
\\
- Kontrak militer \\
- Pasokan persenjataan \\
dan peralatan militer \\
-Pengiriman pasukan dan \\
penasihat militer \\
- Perluasan basis militer \\
\hline
\end{tabular}

\begin{tabular}{|l|}
\hline \multicolumn{1}{|c|}{$\begin{array}{c}\text { Mediasi, negosiasi dan } \\
\text { peace making }\end{array}$} \\
Non-militer: \\
- Deklarasi Moskow \\
- Perundingan \\
perdamaian Astana, \\
Kazakhstan \\
Militer: \\
- Pengurangan \\
penyebaran \\
peralatan militer \\
- Pengurangan kehadiran \\
pasukan militer \\
\end{tabular}

\section{METODE PENELITIAN}

Karya ilmiah ini menggunakan metode penulisan kualitatif dengan teknik pengumpulan data sekunder yang diperoleh melalui teknik studi kepustakaan (library research). Data-data diperoleh dan dikumpulkan dari sumber-sumber yang tertulis yang ada korelasinya dengan kajian yang diteliti, seperti: buku-buku, dokumen, artikel ilmiah, dan berita-berita media massa terutama media massa internasional.

\section{A. Rusia Sebagai Direct Supporter Terhadap Suriah Dalam Konflik Internal Suriah (2011-2015) \\ a. Hak Veto Rusia terhadap Draft Resolusi Dewan Keamanan (DK) PBB dalam Konflik Internal Suriah}


Rusia telah menunjukkan dukungan terhadap rezim Bashar al-Assad dengan membela dan menentang apapun upaya yang dapat melemahkan rezim tersebut sejak awal terjadinya konflik di Suriah pada tahun 2011. Dukungan yang telah diberikan Rusia kepada rezim Bashar al-Assad berupa dukungan non-militer, yaitu veto terhadap draft resolusi Dewan Keamanan (DK) PBB. Veto pertama dijatuhkan pada 4 Oktober 2011 atas draft rancangan resolusi DK PBB S/2016/612 terhadap Bashar al-Assad. Rancangan tersebut mengutuk Suriah dan menuntut rezim Bashar al-Assad untuk menghentikan kekerasan terhadap para demonstran serta mengisyaratkan sanksi jika tuntutan tersebut tidak dilakukan. Namun, rancangan resolusi tersebut tidak dapat dilaksanakan, karena Rusia dan Cina yang merupakan anggota tetap DK PBB mengeluarkan hak vetonya. Alasan Rusia dan Cina menolak rancangan resolusi tersebut karena upaya pengeluaran resolusi tersebut akan membuka peluang pelanggaran kedaulatan Suriah oleh kekuatan asing (Guardian 2011). Selanjutnya, veto kedua dijatuhkan pada 4 Februari 2012 atas draft $\mathrm{S} / 2012 / 77$. Resolusi ini menyatakan keprihatinan atas situasi yang semakin memburuk di Suriah dan keprihatinan atas banyaknya warga Suriah yang meninggal dunia. Resolusi ini mengutuk terhadap pelanggaran hak asasi manusia yang masif di Suriah dan menuntut adanya transisi kekuasaan yang harus dilakukan oleh otoritas Suriah (Harris Paul, Martin Chulov 2012). Rancangan resolusi kedua juga tidak dapat diimplementasikan akibat adanya veto dari Rusia dan Cina. Kemudian, veto ketiga dijatuhkan pada 19 Juli 2012 terhadap draft resolusi S/2012/538. Draft resolusi ini berisi mengenai tuntutan terhadap pemerintah Suriah untuk menghentikan kekerasan di Suriah dan ancaman penjatuhan sanksi terhadap otoritas Suriah (Gabbatt 2012). Rancangan ini kembali di veto oleh Rusia dan Cina. Selanjutnya, veto keempat dijatuhkan pada 22 Mei 2014 atas rancangan S/2014/348 yang berisi mengenai agar konflik Suriah dirujuk ke pengadilan pidana internasional. Rancangan tersebut tetap tidak dapat diwujudkan, karena Rusia dan Cina kembali menggunakan hak vetonya (Black 2014). Menurut Rusia, resolusi DK PBB yang ditujukan atas konflik Suriah membuka peluang bagi pihak asing untuk melakukan intervensi dalam konflik tersebut yang akan melanggar hak-hak kedaulatan Suriah (Menon 2013). Rusia berpegang pada prinsip non-intervention, yaitu menentang intervensi asing dalam penyelesaian konflik di Suriah. Rusia sangat menentang intervensi asing karena menganggap bahwa konflik Suriah merupakan urusan dalam negeri Suriah, sehingga penyelesaiannya harus dilakukan oleh pihak dalam, bukan luar.

\section{b. Bantuan Ekonomi Rusia terhadap Suriah dalam Konflik Internal Suriah}

Konflik Suriah memberikan dampak yang buruk terhadap perekonomian di Suriah. Studi ekonomi oleh Perserikatan Bangsa-Bangsa (PBB), Dana Moneter Internasional dan Ekonom Independen mengatakan bahwa Produk Domestik Bruto (PDB) Suriah adalah setengah dari apa yang terjadi tiga tahun lalu sebelum konflik terjadi, produksi minyak secara efektif terhenti, inflasi mencapai $50 \%$, ekspor dan impor keduanya berkurang hingga $90 \%$ serta angka pengangguran mencapai sekitar 50 \%. Sementara laporan ekonomi Suriah dari editor-in chief, Jihad Yazigi menyampaikan bahwa, pemerintah Suriah tidak memiliki pemasukan yang berarti lagi, investasi dalam negara dan infrastruktur telah menurun serta gaji tetap stagnan (Middle East Eye 2015). Bukan hanya itu, akibat adanya sanksi ekonomi dari dunia internasional terhadap Suriah, membuat perekonomian Suriah menurun. Hal ini 
mendorong pemerintah Bashar al-Assad hampir sepenuhnya tergantung pada pinjaman uang dari Iran dan beberapa bantuan ekonomi dari Federasi Rusia. Moskow memberikan bantuan ekonomi dalam bentuk pinjaman uang terhadap rezim Bashar al-Assad secara berkelanjutan selama konflik Suriah terjadi. Pihak berwenang Suriah telah menerima bantuan senilai $€ 240$ juta pada tahun 2014 dari Rusia. Selanjutnya, pada 17 Desember 2015, sebuah delegasi pejabat Suriah mengunjungi Moskow untuk meminta pinjaman uang sebanyak US\$ 3 miliar untuk rezim Bashar al-Assad (Middle East Eye 2015).

Rusia juga telah memberikan bantuan keuangan melalui bank-bank mereka terhadap Suriah dan mengabaikan sanksi finansial internasional yang terus berdatangan. Suriah memiliki 24 lembaga keuangan yang memiliki hubungan baik dengan Rusia. Bank-bank Rusia tersebut mengizinkan individu dan rezim Suriah untuk menggunakan pelayanan perbankan mereka. Hubungan antara pemerintah Suriah dan sektor perbankan Rusia memungkinkan rezim Bashar al-Assad untuk mempertahankan akses ke mata uang asing dan pasar internasional. Sebagai contoh, terdapat tiga bank Rusia, yaitu VTB Bank, Vnesheconombank (VEB) dan Gazprombank (GPB) yang telah bertransaksi bisnis melalui Bank Umum Suriah untuk membeli senjata bagi rezim Suriah (Jorisch 2013). Selain itu, Rusia juga mencetak uang kertas Suriah yang sebelumnya dipasok oleh Jerman dan Austria hingga Uni Eropa (UE) yang memberlakukan sanksi ekonomi terhadap Suriah (Stott, Michael 2013).

\section{c. Kontrak Militer antara Rusia dan Suriah dalam Konflik Internal Suriah}

Kerjasama militer antara Rusia dan Suriah yang terjalin sejak Perang Dingin berlanjut hingga konflik Suriah terjadi pada tahun 2011. Rusia dan Suriah bekerjasama dalam bidang militer yang ditandai dengan adanya kontrak militer antara kedua negara ini. Bashar al-Assad mengatakan bahwa ada kontrak yang telah disegel mengenai kerjasama militer dan pasokan senjata yang ditandatangani sebelum konflik dimulai dan dilakukan selama konflik berlangsung. Kontrak senjata Rusia dengan Suriah bernilai miliaran dollar (Rosenberg 2012). Pada tahun 2011, kontrak militer senjata aktif antara Rusia dan Suriah telah mencapai US\$ 4 miliar (The Moscow Times 2011) dan kemungkinan akan bertambah sesuai dengan perkembangan konflik. Selanjutnya, pada tahun 2012, kontrak militer antara Rusia dengan Suriah untuk senjata diperkirakan bernilai US $\$ 1,5$ miliar atau sebesar $£ 950$ juta yang terdiri dari 10\% penjualan senjata global Rusia (Galpin 2012). Sementara, menurut Stockholm International Peace Research Institute (SIPRI) kontrak senjata antara Suriah dengan Rusia berjumlah US\$ 687 juta pada tahun 2011 dan 2012 (SIPRI 2013). Kontrak militer untuk persediaan masa depan mencapai beberapa miliar dollar (Tucker 2013).

\section{d. Pasokan Persenjataan dan Peralatan Militer dari Rusia terhadap Pemerintah Suriah dalam Konflik Internal Suriah}

Dari tahap awal konflik Suriah pada tahun 2011, Rusia di bawah kewajiban kontraktualnya dengan Suriah telah mengirimkan pasokan militer berupa amunisi dan persenjataan militer kepada pemerintah Suriah selama konflik berlangsung. Pasokan militer yang dikirimkan Rusia terhadap Suriah merupakan perwujudan kerjasama bilateral dua negara berdaulat di bidang militer. Moskow menegaskan bahwa pengiriman senjata militer itu hanya memenuhi kontrak yang sudah ada 
sebelumnya dan tidak melanggar sanksi internasional. Pengiriman senjata oleh Rusia terhadap pemerintah Bashar al-Assad digunakan untuk melawan kelompok pemberontak (Barry 2012).

Pemerintah Rusia membuat pernyataan yang jelas bahwa pasokan senjata terus berlanjut pada tahun 2011-2012. Ketika protes terhadap Bashar al-Assad dimulai pada tahun 2011, Rusia mengirim hampir US\$1 miliar senjata ke pasukan Suriah (Grove 2013). Moskow membenarkan terkait bantuan senjata-senjata Rusia yang menuju Suriah. Di bawah kepemimpinan Vladimir Putin, pasokan senjata Rusia ke rezim Bashar al-Assad terus meningkat. Menurut Stockholm International Peace Research Institute (SIPRI), impor persenjataan Suriah meningkat lima kali lipat antara 2007-2012 dan Moskow adalah sumber persenjataan untuk Suriah setidaknya $78 \%$. Daftar pasokan senjata dan peralatan militer Rusia di Suriah pada tahun 2012, yaitu (Kenner 2012):

\section{Daftar Pasokan Senjata Rusia di Suriah pada Tahun 2012}

\begin{tabular}{|c|c|c|}
\hline Komponen & Jenis & Keterangan \\
\hline $\begin{array}{l}\text { Mortir dan } \\
\text { cangkang }\end{array}$ & $\begin{array}{l}\text { 240mm buatan } \\
\text { Rusia }\end{array}$ & $\begin{array}{l}\text { Raksasa ini dapat menembakkan } \\
\text { sebuah Shell yang berisi } 280 \text { pon } \\
\text { bahan peledak tinggi pada target } \\
\text { lebih dari enam mil jauhnya dan tidak } \\
\text { hanya dirancang untuk } \\
\text { menghancurkan benteng pertahanan } \\
\text { musuh, tetapi juga dapat } \\
\text { menghancurkan sebuah bangunan } \\
\text { sipil dalam satu tembakan. }\end{array}$ \\
\hline Tank & $\mathrm{T}-72$ & $\begin{array}{l}\text { Menurut International Institute for } \\
\text { Strategic Studies Military Balance } \\
\text { pada tahun } 2011 \text {, tentara Suriah } \\
\text { memiliki } 4.950 \text { tank tempur utama } \\
\text { bersama dengan } 4.000 \text { tank ringan } \\
\text { dan pengangkut personel lapis baja. } \\
\text { Rusia telah memodernisasi } 800 \text { T-72 } \\
\text { untuk militer Suriah dibawah kontrak } \\
\text { baru-baru ini dan } 200 \text { tank lainnya } \\
\text { sedang dalam perjalanan. }\end{array}$ \\
\hline Ranjau darat & $\begin{array}{l}\text { Anti personel } \\
\text { PMN-2 buatan } \\
\text { Rusia dan anti } \\
\text { kendaraan } \\
\text { TMN-46. }\end{array}$ & $\begin{array}{l}\text { Persenjataan Rusia juga membantu } \\
\text { rezim Bashar al-Assad menjebak } \\
\text { warganya didalam negeri, sambil } \\
\text { mencegah senjata dan bantuan dari } \\
\text { luar masuk. }\end{array}$ \\
\hline $\begin{array}{l}\text { Helikopter } \\
\text { serang }\end{array}$ & $\begin{array}{l}\text { S-5 buatan } \\
\text { Rusia }\end{array}$ & $\begin{array}{l}\text { Menembakkan roket ke udara pada } \\
\text { bulan Februari } 2012 \text { dan Angkatan } \\
\text { Darat Suriah baru-baru ini di utara } \\
\text { Idlib dan Aleppo }\end{array}$ \\
\hline Rudal & $\begin{array}{l}\text { MLRS buatan } \\
\text { Rusia }\end{array}$ & $\begin{array}{l}\text { Sistem roket rakitan multi peluncuran } \\
\text { buatan Rusia (MLRS) yang mampu } \\
\text { menembakkan secara bersamaan } \\
\text { hingga } 40 \text { rudal } 122 \text { mm dengan }\end{array}$ \\
\hline
\end{tabular}




\begin{tabular}{|l|l|l|}
\hline & & $\begin{array}{l}\text { target hingga 20 mil jauhnya yang } \\
\text { menghancurkan dan inheren tanpa } \\
\text { pandang bulu. }\end{array}$ \\
\hline Senjata Kimia & $\begin{array}{l}\text { Mencakup } \\
\text { semuanya. } \\
\text { Mulai dari gas } \\
\text { mustard hingga } \\
\text { agen saraf } \\
\text { seperti sarin } \\
\text { dan mungkin } \\
\text { gas VX. }\end{array}$ & $\begin{array}{l}\text { Mungkin yang paling } \\
\text { mengkhawatirkan, Suriah memiliki } \\
\text { persediaan senjata kimia dan biologi } \\
\text { yang sangat besar dan memiliki } \\
\text { mekanisme pengiriman untuk } \\
\text { menggunakannya jika Suriah ingin } \\
\text { melakukannya. }\end{array}$ \\
\hline Pasukan & $\begin{array}{l}\text { musan Laut } \\
\text { melindungi pangkalan Angkatan }\end{array}$ \\
& $\begin{array}{l}\text { Lautnya di kota Tartus, Suriah, satu- } \\
\text { satunya pos militer Moskow di Laut } \\
\text { Tengah. }\end{array}$ \\
\hline
\end{tabular}

Sumber: foreignpolicy.com

Hubungan militer yang erat antara Rusia dan Suriah telah menghasilkan satusatunya pangkalan militer Rusia di luar bekas Uni Soviet, yaitu sebuah fasilitas Angkatan Laut di pelabuhan Tartus, Mediterania. Pangkalan militer ini telah dibangun di pelabuhan Tartus sejak tahun 1963 dan telah digunakan Rusia sejak zaman Perang Dingin berdasarkan perjanjian tahun 1971 sebagai tempat pemeliharaan dan pensuplai Armada Laut Hitam Uni Soviet (Kuncahyono 2012: 148). Pada Januari 2012, Rusia telah mengirim kapal perangnya ke pelabuhan Tartus di Suriah sebagai simbol dukungan terhadap rezim Presiden Bashar alAssad. Selanjutnya, Rusia juga telah mengirimkan 2 kapal amfibi berjenis Nikolai Filchenkov dan Tsezar Kunikov ke Pelabuhan Tartus yang berjarak sekitar 60 mil dari Latakia.

Meskipun terdapat tekanan dari pihak barat, Moskow bersikeras di awal tahun 2013 akan menghormati kontrak yang disepakati sebelumnya dengan Damaskus untuk memasok sistem pertahanan rudal permukaan ke udara canggih S-300 dan berjanji untuk memenuhi kontrak untuk 12 jet tempur MiG-29MM2. Dalam beberapa pekan terakhir pada tahun 2014, Rusia telah meningkatkan pasokan peralatan militer ke Suriah, termasuk kendaraan lapis baja, pesawat tak berawak dan bom yang dipandu. Pesawat angkut Rusia atau Lusinan Antonov 124s telah membawa kendaraan lapis baja, peralatan pengintai, radar, sistem peperangan elektronik, berbagai senjata termasuk bom yang dipandu untuk pesawat ke Suriah (Saul 2014). Pada tahun 2015, Vladimir Putin melanjutkan dukungan militer untuk Bashar alAssad. Putin juga mengajak dan mendesak negara-negara lain untuk bergabung mendukung Rusia dengan mengirimkan bantuan teknis militer. Bashar al-Assad menegaskan bahwa Rusia telah memasok senjata ke Suriah berdasarkan kontrak yang telah ditandatangani sebelum dan sesudah awal konflik (Baczynska 2015). Vladimir Putin mengatakan pada akhir Maret 2015, ekspor senjata Rusia mencapai rekor US\$ 14,5 juta dengan pesanan melonjak menjadi US\$ 56 miliar karena keandalan dan efektivitas tinggi mereka (Aljazeera 2015).

\section{e. Pengiriman Pasukan dan Penasihat Militer Rusia di Suriah dalam Konflik Internal Suriah}


Menteri Luar Negeri Rusia, Sergei Lavrov mengatakan bahwa Rusia terus mengirim pasukan militer dan penasihat ke Suriah sebagai bagian dari kerjasama dan kesepakatan senjata. Tentara dan spesialis militer Rusia yang berada di Suriah bertugas melayani peralatan Rusia dan bekerjasama dengan tentara Suriah dalam menggunakan peralatan militer Rusia. Pada tahun 2012, Rusia menempatkan pasukan militernya di Suriah sebanyak 295.000 personel aktif dan 314.000 personel cadangan. Selanjutnya, pada bulan Juni 2012, sumber keamanan di Damaskus mengungkapkan adanya keberadaan ratusan komando Rusia untuk melindungi rezim Bashar al-Assad dari kudeta militer yang terjadi. Bukan hanya itu, sejumlah penasihat militer yang tidak disebutkan jumlahnya sedang mengajar orang Suriah cara menggunakan senjata Rusia selama tahun 2012 (The scotsman 2012).

Selama konflik Suriah terjadi, Rusia tetap mengirimkan penasihat dan pasukan militer kepada pemerintah Suriah dan menyatakan bahwa pasokan pasukan militer dilakukan untuk memenuhi kontrak bilateral yang ada. Moskow telah mengirim sejumlah pasukan darat, 35 pengangkut personel lapis baja, 200 marinir ke pangkalan udara Suriah dekat Latakia di pantai Mediterania untuk pasukan keamanan pangkalan sebagai bagian dari penumpukan militer yang sedang berlangsung (Schmitt 2015). Sejauh ini, Vladimir Putin telah menempatkan sekitar 500 pasukan pasukan infanteri laut ke kota Latakia untuk melindungi fasilitas pangkalan tersebut. Rusia juga telah menempatkan angkatan lautnya di Mediterania dan beberapa kapal penghancur untuk melindungi Suriah. Selanjutnya, pada tahun 2015, Rusia mengirimkan 200.000 pasukan militer ke Suriah (Blair 2015).

\section{f. Perluasan Basis Militer di Pangkalan Udara Provinsi Latakia, Suriah pada tahun 2015}

Observatorium Suriah, Abdurrahaman yang berbasis di Inggris untuk Hak Asasi Manusia (HAM) mengatakan bahwa pasukan Rusia sedang membangun sebuah landasan udara militer panjang yang mampu menampung pesawat besar di dekat bandara militer Hmeimim di Latakia, Suriah. Sejak memasuki perang, pusat strategis operasi militer Rusia adalah pangkalan udara Hmeimim, Latakia. Latakia merupakan provinsi di pesisir pantai yang menjadi markas pendukung Presiden Bashar alAssad. Bandara yang dikenal dengan nama lama Hmeimim sudah menjadi markas militer kubu pemerintah Suriah dan menjadi bandara yang dikendalikan pemerintah paling penting kedua setelah bandara Damaskus. Bandara Hmeimim saat ini telah berganti nama menjadi Bandar Udara Internasional Bassel al-Assad. Pangkalan udara baru tersebut diperluas dengan tujuan untuk menyediakan titik peluncuran bagi pasukan Rusia (The Associated Press 2015).

Rusia telah meningkatkan secara tajam jumlah pesawat tempur di pangkalan udara Bassel al-Assad yang memberikan kekuatan dan kemampuan baru untuk menyerang sasaran di tanah di negara yang dilanda konflik itu, Suriah. Vladimir Putin telah mengirimkan 12 SU-24 Fencers dan 12 pesawat tempur SU-25 Frogfoots, 15 helikopter militer termasuk Ml-24 tempur dan setidaknya dua baterai dari SA-22 rudal permukaan ke udara serta 28 pesawat tempur di pangkalan baru tersebut. Pengerahan militer oleh Rusia berlanjut dengan pengiriman empat pesawat tempur SU-27 Flankers yang dirancang untuk pertempuran udara ke udara. Selanjutnya, pengerahan beberapa pesawat tempur darat dan jet tempur paling canggih di Rusia serta beberapa sistem pertahanan udara, sistem rudal permukaan ke udara dilengkapi empat pesawat tempur multi pesawat Angkatan Udara Rusia 
SU-30SM di pangkalan dekat rumah keluarga Presiden Bashar al-Assad (Cenciotti 2015). Pesawat-pesawat ini dilindungi oleh setidaknya dua SA-22 dari permukaan ke udara, sistem anti pesawat dan pesawat pengintai, seperti predator yang tidak bersenjata digunakan untuk menerbangi misi pengintaian (Schmitt 2015).

\section{B. Rusia sebagai Mediator terhadap Suriah dalam Konflik Internal Suriah (2016-2017) \\ a. Deklarasi Moskow: 20 Desember 2016}

Rusia yang menjalin aliansi lama dengan Iran, kini mulai membangun aliansi baru dengan Turki untuk mengakhiri konflik di Suriah yang sudah berlangsung hampir enam tahun lamanya. Pada 20 Desember 2016, para Menteri Luar Negeri dan Pertahanan ketiga negara tersebut bertemu di Moskow untuk membahas penyelesaian damai di Suriah. Menteri Luar Negeri Iran, Mohammed Javad Zarif, Menteri Luar Negeri Rusia, Sergey Lavrov dan Menteri Luar Negeri Turki, Mevlut Cavusoglu menyatakan niat mereka untuk menghentikan konflik Suriah tanpa melibatkan Amerika Serikat dan Inggris. Sergei Lavrov mengatakan bahwa pihakpihak yang mengikuti pertemuan ini adalah pihak yang memiliki pengaruh nyata di Suriah dan hal ini tidak terjadi pada Inggris dan Amerika Serikat (Hubbard 2016).

Upaya perdamaian yang dimediasi oleh Rusia, Iran dan Turki dilakukan setelah sebelumnya semua upaya yang dilakukan oleh Amerika Serikat dan koalisinya dengan harapan untuk mencapai kesepakatan damai di Suriah gagal. Menteri Pertahanan Rusia, Sergei Shoigu menyatakan tidak satupun dari mereka memiliki pengaruh nyata atas situasi di lapangan. Belum ada hasil yang dicapai sejauh ini dalam kerangka Kelompok Dukungan Suriah Internasional yang ditengahi oleh PBB. Sergei Shoigu, juga menyebutkan bahwa hanya dukungan Rusia yang mampu membuat perbedaan nyata dalam konflik Suriah melalui kesepakatan yang tertulis (laconangelo 2016). Diskusi pada 20 Desember 2016 antara Rusia, Iran dan Turki berakhir dengan mengadopsi Deklarasi Moskow delapan poin berisikan kerangka kerja untuk mengakhiri konflik di Suriah melalui upaya perluasan gencatan senjata (Osborn 2016). Ketiga negara telah bersedia memfasilitasi penyusunan perjanjian yang telah dinegosiasikan antara pihak pemerintah Suriah dan kelompok oposisi. Rusia, Turki dan Iran mengeluarkan pernyataan perluasan seruan gencatan senjata dan menegaskan opsi politik di Suriah, dimana mereka sepakat untuk bertindak sebagai penjamin dalam Deklarasi Moskow.

Salah satu prinsip Deklarasi Moskow adalah pernyataan eksplisit dari ketiga negara, bahwa tidak akan ada resolusi militer dari konflik Suriah. Didalam teks itu juga mengakui keterlibatan kelompok-kelompok oposisi, kecuali Front al-Nusra dan ISIL untuk bergabung ke dalam dialog politik dengan rezim Suriah saat ini mengenai masa depan Suriah. Selanjutnya adalah pengakuan eksplisit atas perjanjian internasional, termasuk pengakuan terhadap peran penting PBB dalam upaya memecahkan konflik Suriah sesuai dengan resolusi Dewan Keamanan (DK) PBB 2254. Kemudian, poin yang disetujui dalam deklarasi tersebut adalah semua orang setuju bahwa Suriah tetap bersatu di bawah sistem demokratis atau sekuler. Rusia, Iran dan Turki menekankan kedaulatan dan kemerdekaan Suriah. Ketiga negara tersebut menyerukan pencegahan disintegrasi Suriah demi persatuan melalui penghentian permusuhan ke seluruh bagian negara dan integritas teritorial Suriah 
sebagai sebuah negara multi etnis, multi agama, non sektarian dan demokratis (Parstoday 2016).

\section{b. Putaran Perundingan Perdamaian Astana: Januari - Desember 2017}

Intervensi Rusia yang sangat penting dalam menyelamatkan rezim Bashar al-Assad telah mengubah konflik dengan menormalkan hubungan antara Rusia dan Turki pada musim panas lalu. Kedua negara tersebut menjadi penjamin dalam perundingan perdamaian di Astana, Kazakhstan demi terciptanya perdamaian di Suriah. Selama tahun 2017, Rusia, Turki dan Iran telah telah melakukan delapan perundingan perdamaian di Astana, Kazakhstan dengan membahas isu-isu yang dinegosiasikan sehingga menghasilkan beberapa kesepakatan, seperti kesepakatan mengenai pemerintah Suriah dan kelompok oposisi telah menyetujui gencatan senjata nasional yang diumumkan oleh Vladimir Putin dan dikonfirmasi oleh Turki sebagai penjamin dalam resolusi konflik Suriah, menciptakan zona de-eskalasi di Suriah untuk mengurangi ketegangan antara pihak pemerintah Suriah dengan kelompok pemberontak dan memperbaiki situasi kemanusiaan serta mempelajari peluang baru untuk memperluas kerjasama trilateral di Suriah (Orazgaliyeva 2017). Pembicaraan perdamaian di Astana, Kazakhstan tersebut pertama kali menyertakan pemerintahan Suriah, kelompok oposisi bersenjata Suriah, delegasi dari Rusia, Iran, Turki, Utusan Khusus Sekretaris Jenderal PBB untuk Suriah, Staffan de Mistura, perwakilan dari Yordania serta dari perwakilan dari negara lainnya (Bbc news 2017).

Moskow yakin bahwa pembicaraan di Moskow dan Astana akan lebih menguntungkan daripada perundingan yang gagal sebelumnya. Hal ini sebagian bisa dikarenakan kekuatan kelompok oposisi telah melemah akibat kekalahan kelompok oposisi di wilayah Aleppo dan beberapa wilayah lainnya selama tahun 2016. Selain itu, Rusia juga percaya bahwa Washington dibawah kepemimpinan Donald Trump lebih tertarik dalam mengalahkan kelompok militan terutama ISIS, dari pada memaksa Bashar al-Assad untuk turun dari kursi pemerintahan (Guardian 2017). Hal ini sesuai dengan pernyataan Donald Trump bahwa mengalahkan Negara Islam (IS) adalah prioritas yang lebih tinggi daripada membujuk Bashar alAssad untuk mundur dari jabatannya (Nichols 2017).

Sejak intervensi militer Rusia pada September tahun 2015, Moskow telah berhasil mengubah arus dalam perang sipil enam tahun Suriah yang mendukung Presiden Bashar al-Assad dengan cepat menjadikan dirinya sebagai penengah utama dalam mewujudkan perdamaian di wilayah tersebut. Lebih jauh lagi, Moskow telah berusaha mempengaruhi dan menarik perhatian dengan lebih banyak aktor regional dalam upaya untuk mengakhiri konflik Suriah. Selain itu, Rusia juga menunjukan kesediaan dan kesiapannya untuk bersatu dengan barat terkait krisis regional yang membutuhkan penyelesaian dari pemain-pemain global. Bagi Moskow, proses negosiasi yang telah dilakukannya tersebut dapat menjadi jalur cepat untuk mencapai perdamaian di Suriah selain upaya dari forum internasional lainnya.

\section{c. Pengurangan Penyebaran Peralatan Militer Rusia di Suriah dalam Konflik Internal Suriah pada tahun 2017}

Pada tanggal 6 Januari 2017, sesuai dengan keputusan Panglima Tertinggi Angkatan Bersenjata Rusia, Vladimir Putin, maka Kepala Staf Umum Angkatan Bersenjata Rusia, Jenderal Valey Gerasimov mengumumkan bahwa Kementerian 
Pertahanan Rusia mulai mengurangi penyebaran peralatan miliiter di Suriah (Wintour 2017). Perintah tersebut diinstruksikan oleh Presiden Rusia setelah tercapainya kesepakatan gencatan senjata dengan Iran dan Turki pada tanggal 30 Desember 2016 antara kelompok oposisi dan rezim Suriah (Reuters 2017b).

Rusia ingin meningkatkan pengaruh terhadap Iran, Turki dan Suriah untuk menjadi penjamin yang netral dalam penyelesaian konflik Suriah, serta mendorong mereka untuk mematuhi gencatan senjata yang baru-baru ini disepakati guna mendorong keberhasilan militer pasukan mereka menjadi kesuksesan pada level politik dalam konflik Suriah. Gerasimov mengatakan bahwa langkah Rusia menarik sebagian kekuatan militernya juga sebagai tawaran kesempatan untuk mengakhiri konflik bersenjata selama enam tahun tersebut (Sadjimo 2017). Pengurangan militer ini dimulai dari kelompok kapal induk dengan penarikan kapal induk Rusia, Admiral Kuznetzov dilengkapi dengan jet tempur dan helikopter lapis baja. Kapal perang tersebut menjadi gelombang pertama yang ditarik mundur dari wilayah konflik itu tepatnya dari pelabuhan Tartus ke Murmansk (Spark 2017). Angkatan Laut Rusia juga menarik kapal lainnya dari Laut Tengah, seperti kapal Battlecruiser Pyotr Veliky bertenaga nuklir dan kapal Destroyer yang akan kembali ke markasnya di Severomorsk, Rusia (Reuters 2017a).

\section{d. Pengurangan Kehadiran Pasukan Militer Rusia di Suriah dalam Konflik Internal Suriah pada tahun 2017}

Pada tanggal 11 Desember 2017, Presiden Rusia, Vladimir Putin mengadakan kunjungan dadakan ke Suriah dan bertemu dengan Presiden Bashar al-Assad di pangkalan militer Rusia, Hmeimim, Latakia, Suriah. Dalam pertemuan tersebut, Vladimir Putin memerintahkan Menteri Pertahanan Rusia dan Kepala Staf Umum Angkatan Bersenjata Rusia, Jenderal Valey Gerasimov untuk melakukan penarikan sejumlah besar kontingen militer mereka dari Suriah ke markas permanen mereka masing-masing di Rusia (CNN Indonesia 2017). Pasukan militer Rusia telah berada di Suriah demi misinya untuk mendukung rezim Bashar al-Assad dalam menghadapi serangan dari kelompok pemberontak. Penarikan pasukan militer tersebut diinstruksikan oleh Vladimir Putin setelah adanya gencatan senjata nasional yang dinegosiasikan antara Rusia, Turki, Iran dan pemerintah Suriah serta kelompok pemberontak pada akhir tahun 2016 demi terciptanya solusi damai di Suriah. Selanjutnya, sesuai dengan keputusan panglima tertinggi angkatan bersenjata Rusia, Vladimir Putin, Kementerian Pertahanan Rusia, Gerasimov segera mulai mengurangi armada Angkatan Laut Rusia yang bertugas di Suriah untuk meninggalkan zona konflik di Suriah. Armada Angkatan Laut Rusia yang bertugas di Suriah tersebut dipimpin oleh kapal induk Admiral Kuznetsov. Kepala Staf Umum Militer Rusia, Jenderal Valey Gerasimov mengatakan bahwa penarikan sejumlah peralatan dan pasukan militer Rusia dari Suriah sebelum akhir tahun kemungkinan akan menyebabkan ukuran kekuatan militer Rusia di Suriah akan berkurang secara signifikan (Reuters 2017a).

\section{KESIMPULAN}

Konflik Suriah yang terjadi sejak tahun 2011 hingga kini semakin rumit dikarenakan semakin banyaknya negara lain yang terlibat dalam konflik tersebut. Rusia sebagai sekutu utama Suriah di Kawasan Timur Tengah telah bertindak dan mengarahkan 
politik luar negerinya menjadi direct supporter terhadap rezim Bashar al-Assad sejak konflik Suriah bergejolak pada tahun 2011 melalui dukungan non-militer dan militer. Dalam bentuk dukungan non-militer, Rusia menggunakan hak vetonya untuk menggagalkan resolusi kritis Dewan Keamanan (DK) PBB terhadap rezim Bashar alAssad. Dari tahun 2011 hingga 2015, Rusia telah empat kali menjatuhkan veto terhadap draft rancangan resolusi DK PBB terkait Suriah. Selanjutnya, Rusia memberikan bantuan ekonomi berupa pinjaman uang dan akses layanan perbankan Rusia terhadap rezim Bashar al-Assad. Sementara dalam bentuk dukungan militer, Rusia telah menjalin kerjasama bilateral dengan Suriah dibidang militer. Hubungan kerjasama militer tersebut ditandai dengan adanya kontrak senjata antara kedua negara yang bernilai miliaran dollar, pasokan persenjataan dan peralatan militer Rusia terhadap rezim Bashar al-Assad, pengiriman pasukan dan penasihat militer Rusia ke Suriah serta perluasan basis militer di dekat bandara Hmeimim, provinsi Latakia, Suriah. Akan tetapi, setelah koalisi besar antara pasukan pemerintah Suriah dan militer Rusia berhasil merebut kota Aleppo dan mengeluarkan kelompok oposisi dari wilayah tersebut pada akhir tahun 2016, pola dari bentuk politik luar negeri Rusia terhadap Suriah berubah. Dari segi non-militer, Rusia bersama dengan Turki dan Iran segera mengadakan pertemuan tripartit untuk membahas solusi damai di Suriah. Dalam konferensi tersebut, ketiga negara berhasil menyepakati sebuah perjanjian damai yang disebut Deklarasi Moskow yang berisikan kerangka kerja untuk mengakhiri konflik di Suriah melalui upaya perluasan gencatan senjata. Selanjutnya, Rusia juga menjadi penjamin dalam proses negosiasi dengan menginisiasi perundingan perdamaian di Astana, Kazakhstan yang pertama kalinya menghadirkan pihak kelompok pemberontak dan pemerintah Suriah untuk duduk bersama di arena internasional guna mencapai alternatif kebijakan dalam mencari solusi damai pada konflik Suriah. Selama tahun 2017, Rusia bersama Turki dan Iran telah melakukan delapan putaran pertemuan perundingan di Astana, Kazakhstan dengan berbagai isu-isu yang telah dinegosiasikan, seperti gencatan senjata, zona de-eskalasi dan termasuk isu kemanusiaan. Sementara dari segi militer, Rusia telah mengurangi sejumlah besar penyebaran peralatan militer dan kehadiran pasukan militer di Suriah untuk mendukung upaya penyelesaian damai di Suriah.

\section{REFERENSI}

Aliyeva, Kamila. 2017. Russia to Reduce Military Presence in Syria. https://www.azernews.az/region/122801.html.

Aljazeera. 2015. How Is Russia Financing Its War in Syria?

Austin, Jon. 2017. US and NATO Want Syria to Be next Libya-Claims Assad and Putin "GOOD Guys" of Conflict. https://www.express.co.uk/news/weird/836154/Syria-War-Vladimir-Putin-RussiaPresident-Assad-good-guys-Nato.

Baczynska, Gabriela and Darya Korsunskaya. 2015. Syria Gets Russian Arms under Deals Signed since Conflict Began: Assad. https://www.reuters.com/article/ussyria-crisis-russia-arms/syria-gets-russian-arms-under-deals-signed-sinceconflict-began-assad-idUSKBNOMQ0RK20150330.

Barry, Anya. 2012. "Adding Fuel to Syria's Fire." https://fpif.org/adding_fuel_to_syrias_fire/.

Bbc news. 2017. Syria Conflict: Rebels Agree to Attend Astana Peace Talks. https://www.bbc.com/news/world-middle-east-38636224.

BBC News. 2016. Syria Conflict: Ceasefire Agreed, Backed by Russia and Turkey. 
http://www.bbc.com/news/world-middle-east-38460127.

Black, lan. 2014. Russia and China Veto UN Move to Refer Syria to International Criminal Court. https://www.theguardian.com/world/2014/may/22/russia-chinaveto-un-draft-resolution-refer-syria-international-criminal-court.

Blair, David and Tom Whitehead. 2015. Russian Jets in Syria Mean No-Fly Zone Is "out of the Question", Warn Experts. https://www.telegraph.co.uk/news/worldnews/middleeast/syria/11883107/Russia n-jets-in-Syria-mean-no-fly-zone-is-out-of-the-question-warn-experts.html.

Cenciotti, David. 2015. New Satellite Image Unveils an Impressive Line-up of 12 Russian Su-25 Frogfoot Attack Jets in Syria!

CNN Indonesia. 2017. Misi Berhasil, Putin Tarik Pasukan Dari Suriah. https://www.cnnindonesia.com/internasional/20171212083205-120-261741//misiberhasil-putin-tarik-pasukan-dari-suriah.

Filipov, David, Erin Cunningham and Kareem Fahim. 2016. Russia, Turkey Issue "Moscow Declaration", Say They Plan to Halt Syrian War. https://www.smh.com.au/world/russia-turkey-issue-moscow-declaration-saythey-plan-to-halt-syrian-war-20161221-gtfndj.html.

Folberg, Jay and Alison Taylor. 1984. Mediation. San Francisco: Jossey-Bass.

Friedman, Brandon. 2017. "Russia, Turkey, and Iran: Cooperation and Competition in Syria." Tel Aviv University 11(2): 5.

Gabbatt, Adam. 2012. Russia and China Veto of Syria Sanctions Condemned as "Indefensible." https://www.theguardian.com/world/2012/jul/19/russia-chinasyria-sanction-veto.

Galpin, Richard. 2012. Russian Arms Shipments Bolster Syria's Embattled Assad. https://www.bbc.com/news/world-middle-east-16797818.

Galtung, Johan. 1996. Peace By Peaceful Means: Peace and Conflict, Development and Civilization. Oslo: International Peace Research Institute.

Goldstein, Joshua S. 1994. International Relations. Washington: Harper Collin College and Publisher.

Grove, Thomas. 2013. Insight: Syria Pays for Russian Weapons to Boost Ties with Moscow.

https://www.reuters.com/article/us-usa-immigrationmelaniatrump/melania-trump-visits-arizona-migrant-shelter-as-protests-mountidUSKBN1JO2NA.

Guardian. 2011. Russia and China Veto UN Resolution against Syrian Regime. https://www.theguardian.com/world/2011/oct/05/russia-china-veto-syriaresolution.

- 2017. Russia-Syria Talks Astana Kazakhstan. https://www.theguardian.com/world/2017/jan/22/russia-syria-talks-astanakazakhstan-\&prev=search.

Harris Paul, Martin Chulov, David Batty and Damien Pearse. 2012. Syria Resolution Vetoed by Russia and China at United Nations. https://www.theguardian.com/world/2012/feb/04/assad-obama-resign-unresolution.

Hearst, David. 2012. Why Russia Is Backing Syria. https://www.theguardian.com/commentisfree/2011/dec/02/russia-syria-civil-wardagestan.

Hubbard, Ben and David E. Sanger. 2016. Russia, Iran and Turkey Meet for Syria Talks, 
meet-for-syria-talks-excluding-us.html.

laconangelo, David. 2016. "Moscow Declaration" Lays out Vision for Syrian Peace Deal, with US on Sidelines. https://www.csmonitor.com/World/2016/1221/Moscow-Declaration-lays-outvision-for-Syrian-peace-deal-with-US-on-sidelines.

Jorisch, Avi. 2013. In Syria, Go after Banks before Bombs: Column.

Kenner, David. 2012. What Russia Gave Syria. https://foreignpolicy.com/2012/06/21/what-russia-gave-syria/.

Kreutz, Andrej. 2010. Syria: Russia's Best Asset in the Middle East. Paris: Russia/NIS Center.

Kuncahyono, Trias. 2012. Musim Semi Di Suriah: Anak-Anak Penyulut Revolusi. Jakarta: Kompas Nusantara.

Lee, Dmitry dan Galiaskar Seitzhan. 2017. Latest Astana Process Talks Establish De-Escalation Zones In War Torn Syria. http://astanatimes.com/2017/05/latestastana-process-talks-establish-de-escalation-zones-in-war-torn-syria/.

Leidhoidt, Ulrich dan Saloh, Christa (Editor: Ayu Purwaningsih). 2012. Liga Arab Sepakati Sanksi Terhadap Suriah. http://www.dw.de/liga-arab-sepakati-sanksiterhadap-suriah/a-15561080.

Mark R. Amstutz. 1999. International Conflict and Cooperation: An Introduction to World Politics. McGraw-Hill.

Menon, Rajan. 2012. What's Russia Doing in Syria and Why. https://www.huffingtonpost.com/rajan-menon/whats-russia-doing-insyr_b_3375715.html.

Middle East Eye. 2015. Syria's Assad Depending on Iran Financial Aid. https://www.middleeasteye.net/news/syrias-assad-depending-iran-financial-aid392275455.

Nichols, Michelle. 2017. U.S. Priority on Syria No Longer Focused on "Getting Assad out": Haley. https://www.reuters.com/article/us-mideast-crisis-syria-usa-haley/us-priority-on-syria-no-longer-focused-on-getting-assad-out-haleyidUSKBN1712QL.

Orazgaliyeva, Malika. 2017. Kazakhstan Welcomes Results of Syria Meeting in Astana, as Russia, Iran and Turkey Issue Joint Statement. http://astanatimes.com/2017/03/kazakhstan-welcomes-results-of-syria-meetingin-astana-as-russia-iran-and-turkey-issue-joint-statement/.

Osborn, Andrew. 2016. Russia Says Drafting Document to Resolve Syria Conflict with Turkey, Iran. https://www.reuters.com/article/us-mideast-crisis-syria-russiadeclarati/russia-says-drafting-document-to-resolve-syria-conflict-with-turkeyiran-idUSKBN1491JS.

Parstoday. 2016. Dukungan PBB Untuk Deklarasi Moskow. http://parstoday.com/id/news/middle_east-i29494dukungan_pbb_untuk_deklarasi_moskow.

Reuters. 2017a. Russia Plans to Significantly Reduce Its Troops in Syria by the End of 2017.

—. 2017b. Russia Says Has Begun Reducing Forces in Syria. https://www.reuters.com/article/us-mideast-crisis-syria-russia-militaryidUSKBN14Q0USI.

Rosenberg, Steven. 2012. Why Russia Sells Syria Arms. http://www.bbc.com/news/world-europe-18642032.

- 2017. Syria War: Putin's Russian Mission Accomplished. 
http://www.bbc.com/news/world-europe-42330551.

Russia Beyond. 2017. Ingin Damaikan Suriah, Rusia Berupaya Keras Jadi Penjamin Solusi Konflik. https://indonesia.rbth.com/politics/2017/01/27/ingin-damaikansuriah-rusia-berupaya-keras-jadi-penjamin-solusi-konflik_wyx689801.

Sadjimo, Sawitri. 2017. Kurangi Kehadiran Militer Di Suriah, Rusia Ingin Capai Kesuksesan Politik.

Sarafindo, Edwar P. 1997. Health Psychology, Biopsychological Interactions. New York: Hohn Wiley \& Sons.

Saul, Jonathan. 2014. Exclusive: Russia Steps up Military Lifeline to Syria's Assad Sources. https://www.reuters.com/article/us-syria-russia-armsidUSBREA0G0MN20140117.

SBS News. 2013. Timeline: Syria's Relations with Russian'. https://www.sbs.com.au/news/timeline-syria-s-relations-with-russia.

Schmitt, Eric and Neil MacFarquhar. 2015. Russia Expands Fleet in Syria With Jets That Can Attack Targets on Ground. https://www.nytimes.com/2015/09/22/world/middleeast/russia-deploys-groundattack-aircraft-to-syrian-base.html.

Shaheen, Kareem, Torpey, Paul, Gutiérrez, Pablo, Levett, Cath. 2015. Who Backs Whom in the Syrian Conflict. https://www.theguardian.com/world/nginteractive/2015/oct/09/who-backs-whom-in-the-syrian-conflict.

Sharnoff, Michael. $2009 . \quad$ "The Syria-Soviet Alliance." http://www.jewishpolicycenter.org/833/the-syria-soviet-alliance.

SIPRI. 2013. "SIPRI Arms Transfers Database." http://armstrade.sipri.org/armstrade/page/values.php.

Sly, Liz and Suzan Haidamous. 2017. At Russia-Led Talks, Syrian Rebels and Government Meet for the First Time. https://www.washingtonpost.com/world/atrussia-led-talks-syrian-rebels-and-government-meet-for-the-firsttime/2017/01/23/e6373d5e-df65-11e6-8902610fe486791c_story.html?utm_term=.1e89421db22e.

Spark, Laura Smith and Frederik Pleitgen. 2017. Russia "Starts to Withdraw" Forces from Syria.

Stott, Michael, Nakhoul Samia. 2013. Syria Expects More Financial Aid from Russia, Iran.

Tamburaka, Apriadi. 2011. Revolusi Timur Tengah: Kejatuhan Para Penguasa Otoriter Di Negara-Negara Timur Tengah. Yogyakarta: Narasi.

The Associated Press. 2015. Syria Group: Russia Expanding Major Syrian Airport. https://www.militarytimes.com/news/your-military/2015/09/13/syria-group-russiaexpanding-major-syrian-airport/.

The Moscow Times. 2011. News Analysis: Russia Damages Image in Arab Spring. https://themoscowtimes.com/articles/news-analysis-russia-damages-image-inarab-spring-9152.

The scotsman. 2012. Syria: Moscow Sends Navy Vessels to Syrian Port. https://www.scotsman.com/news/world/syria-moscow-sends-navy-vessels-tosyrian-port-1-2362099.

Tucker, Joshua. 2013. Why Is Syria So Important to Russia and Putin? http://themonkeycage.org/2013/09/why-is-syria-so-important-to-russia-andputin/.

Wilson, Nigel. 2014. Syria: Russia Boosts Financial Aid to Bashar Al-Assad Regime.

Wintour, Patrick. 2017. Russia Begins Military Withdrawal from Syria. 
Jurnal Dinamika Pemerintahan

Vol.3, No. 1 (Januari 2020)

doi: 10.36341/jdp.v3i1.1192

https://www.theguardian.com/world/2017/jan/06/russia-aircraft-carriermediterranean-syria-admiral-kuznetsov. 